\title{
Sexual Violence and HIV/AIDS Risks in Kenyan \& Ugandan Schools: Social Implications for Educational Policy Development
}

\author{
Njoki Wane ${ }^{1}$ \\ University of Toronto \\ E-mail: nwane@oise.utoronto.ca
}

\begin{abstract}
With sexual violence becoming widespread in Kenyan and other schools in the region, this paper specifically investigates problems of sexual assault and the heightened risks of HIV/AIDS in Kenyan and Ugandan schools. The paper is based on research undertaken in the concerned areas in 2006. To provide an effective descriptive and, by extension, analytical backdrop for the case, the paper provides important background information based on available literature on sexual violence in schools. As noted below, some of the major factors contributing to increased cases of sexual violence and rising incidences of HIV/AIDS in Kenyan and Ugandan schools are also presented. With that in place, issues related to policy development and possibilities of implementing those policies to address the problem of sexual violence in Kenyan and Uganda schools are examined, with recommendations for policies and programs provided.
\end{abstract}

\section{Introduction}

Sexual violence incidences have become rampant in Kenyan schools. However, anecdotal evidence available, usually in the form of media reports, has mainly pointed to the vulnerability of schoolgirls to violence and abuse and the implications for education access (Omale, 2003). This leaves knowledge about the links between sexual violence, the spread of HIV/AIDS and strategies to combat the problem obscure. The emerging discussions on issues of violence have highlighted the high risk women and girls in Kenyan and Ugandan societies face today, due to cultural, political and economic factors.

It is difficult to accurately estimate the prevalence of sexual violence in Kenya because of the limited amount of research done on the subject. The available information is usually in the form of media reports. For example, since 1991, not a year has gone by in Kenya without at least one incident of school violence. Worst incidents include the 1991 St. Kizito Girls High School tragedy, the 1998 Bombolulu Girls' School tragedy and the 1999 Nyeri High School tragedy. In these incidences, many girls lost their lives, many others were injured and almost all were raped (See Republic of Kenya, 2001; East

\footnotetext{
${ }^{1}$ I would like to express my gratitude to the Catholic University of Eastern Africa for giving me an opportunity to collaborate in this research during my sabbatical in Kenya (2005-2006). I am grateful to the Research Department of the University for providing the necessary funds to carry out the research and, in particular, I would like to express my gratitude to Professor Paul Ogula for his commitment to this type of research. Thank you to Professors Machyo, Adibo, and Ndolo and all the graduate assistants for your participation in this research. In addition, I would like to thank Salome Owinyo, for carrying out the literature review for the research project, and for Nairesiae for agreeing to read a draft of this paper.
}

Journal of Contemporary Issues in Education, 2009, 4(1), pp. 71-91.

ISSN 1718-4770 (C) 2009 University of Alberta

http://ejournals.library.ualberta.ca/index.php/JCIE 
African Standard, 2003; Atemi, 2000). There are also silent cases that go unreported especially in rural schools. Although there are no specific data documenting incidences of sexual violence in schools, girls' schools are often targets. Furthermore, the experience of violence has been found to be a strong predictor of HIV/AIDS (Maman \& Campbell, 2000). As a result of violence, girls and women who have been sexually assaulted are at increased risk of HIV infection, through direct transmission, and because of the long-term effects of sexual violence on risk-taking behavior. This raises some important questions such as: what factors contribute to the increased waves of violence in Kenyan schools? What steps have concerned authorities taken to curb the vice? What government policies have been put in place to deal with the problem of sexual violence? These questions call for in-depth research into the root causes of sexual violence and impediments to addressing the vice in Kenya.

This paper is based on a research project on sexual violence in Kenyan and Ugandan schools that was conducted in 2006. The paper provides background information based on available literature on sexual violence in schools. Problems of sexual violence and the increased risks of HIV/AIDS in Kenyan and Ugandan schools are examined. The factors contributing to increased cases of sexual violence and spread of HIV/AIDS in Kenyan and Ugandan schools are also presented. In lieu of these factors, challenges to policy development and implementation to address the problem of sexual violence in Kenyan and Uganda schools is examined and recommendations for policy and practice provided.

\section{Literature Review}

The gender violence acts in most African schools range from sexual abuse through aggressive and intimidating behaviour, indecent assault, coercive sex, defilement and rape of the girl-child by either fellow male students, teachers, lecturers, school administrators and even members of the community who invade the schools (COVAW, 2005). In Kenya, some of the reported incidences include: The St. Kizito tragedy on July 13, 1991, whereby 71 girls aged between 14-18 years were raped, leading to the deaths of 19 of them following strangulation and being crashed under iron bunk beds in the ensuing violence; Keveye Girls School in Vihiga district in 1996 where three male teachers were implicated for impregnating 12 girls at the same time; Mareira Mixed Secondary School ordeal in the Murang'a District, whereby a number of girls were attacked and raped by their male colleagues and villagers on July 7, 1996 with the culprits later also burning down the school; Bombululu Girls High School (1998) where 30 girls were burnt to death and the most recent incidence in 2006 at Kangumbiri Girls High School in Nyeri district where 3 girls were raped. In Ethiopia, gender violence has been reported in Addis Ababa, whereby according to Terefe and Mengistu (1997), 20 percent of the 240 violent incidents reported in schools in and around Addis Ababa in 1996 were in the form of attempted rape. In South Africa, reported incidences of sexual violence are seen in the works of Jewkes et al. (2002) who, in their 1998 study of the frequency of rape among a nationally representative sample of 11,735 South African women aged 15-49, found that of the 159 women who had been the victims of child rape (under the age of 15), 33 percent had been raped by teachers. In Ghana, a survey of violence against women and adolescent girls reported that 49 percent of the 481 adolescent girls surveyed had been 
touched against their will at some time in their lives, 12 percent of the offenders being pupils and 2 percent teachers; 4 percent of sexual assaults on adolescent girls were by fellow pupils and 2 percent by teachers (Appiah \& Cusack, 1999).

From this review of literature, it is clear that there is limited research on the link between sexual violence and HIV/AIDS risks, in spite of increased concerns about rising cases of HIV/AIDS among youth of school age. In 2002, it is estimated that 37.8 million adults and children were living with HIV/AIDS including 10 million young people between the ages of 15 and 24. Indeed, worldwide, half of all new HIV infections are in young people aged 10 to 25 . According to Dunne et al. (2006) the epidemic's 'feminization' is most apparent in sub-Saharan Africa, where close to 60 percent of those infected are women and 75 percent of young people infected are girls aged 15-24 years. Mirsky (2003) adds that much of the gender violence in schools comes from sub-Saharan Africa, where the girls are five to six times more likely to be HIV positive than boys of the same age. In Kenya, the HIV/AIDS pandemic has greatly impacted on the provision of education due to the high numbers of teachers dying of HIV/AIDS and the many AIDS orphans currently estimated at over 6,000 per annum and 1.3 million respectively (MOEST, 2001). Although the magnitude of the pandemic is not well documented on a national basis, there are indicators that the education sector is losing many qualified human resources (Otieno, 2000). It has been estimated that 11.8 percent of all children below 15 years will be orphaned due to AIDS by the year 2020 (Kelly, 2003). It is also estimated that nationally up to 20 percent of pupils between 14 and 17 years of age are infected, with the majority of them being girls (Yildiz, 2000). In some regions, it is estimated that 10 to 20 teachers die of the disease every month leading to an estimated 2,500 Kenyan classrooms without teachers due to HIV/AIDS related deaths according to Elimu Yetu Coalition (EYC, 2003). Abagi (2001) further reports that, class sizes have been reduced from between 45-50 pupils to about 20-25 pupils and that universities lose an average of four people, both lecturers and students per week to AIDS. Research carried out in schools in an urban region in Kenya, discovered that in primary schools, 17 percent of the 22,139 pupils were HIV positive. The situation was worse in secondary schools where 22 percent of the 5,531 students tested HIV positive. (Mumero \& Onunga, 2001). Available data further indicates that up to 860,000 children in sub-Saharan Africa went without teachers in 1999 due to AIDS, out of which 95, 000 (11 percent) were in Kenya.

These challenges have prompted several initiatives by governments and various agencies in attempting to control and prevent the scourge. In Kenya, there have been attempts to promote HIV/AIDS awareness by incorporating it into the education curriculum and there are also many school-focused campaigns. However, Aduda (2001) contends that the focus of these campaigns has been more on information and awareness creation rather than on how to deal with its impact. Research, in one of the districts in Kenya, noted that the institutionalization of HIV/AIDS did not seem to impact on the behaviour of some of the youth who were involved in prostitution (Owinyo, 2006). Njagi (2005) also contends that, in spite of the integration into the curriculum, the curricular guides remain unclear since HIV/AIDS is not part of the examinable curriculum in Kenya. Another challenge that is experienced within the education sector, particularly in developing contexts, is the cultural element of patriarchy, whereby the male culprits 
involved in gender violence often go unpunished as the practice in some regions seems to have been normalized and is tolerated. From their study on sexual violence among pupils in a South African township, Wood and Jewkes (1998) found that physical assault, rape and coercive sex has become the norm, making it very difficult for young women to protect themselves against unwanted sexual intercourse or pregnancy, HIV infection, and other sexually transmitted diseases. Leach and Machakanja (2000) and Leach et al. (2003) also examined the abuse of junior secondary school girls by older boys, teachers and sugar daddies in Zimbabwe, Ghana and Malawi and found that there was a high level of sexual aggression from boys, which went largely unpunished in the schools, and, in some cases, male teachers who forced girls into sexual contacts only got transferred to other schools without any disciplinary action taken towards them. This has also been evident in Kenya, where according to COVAW's report on the St. Kizito incident, the ordinariness of the act was provided by then deputy head teacher of the school, who stated that, "the boys never meant any harm against the girls, they only wanted to rape." They further report that shortly after the incident, a probation officer stated, "if you are a girl, you take it and hope that you don't get pregnant" (COVAW, 2005, p. 6).

\section{The Study}

Data utilized in this paper was generated through qualitative and quantitative approaches. A total of 29 and 5 schools were visited in Kenya and Uganda respectively. Two thousand five hundred questionnaires were distributed out of which 2074 were completed and returned to the investigators (82 percent response). In Kenya, the students who completed the questionnaire and participated in the focus group discussion were from the following districts: Kwale (214) Mombasa (424), Kilifi (56), Meru South (80), Embu (530), Mbeere (83), Machakos (24), Kisumu (158), Kampala (466), and not stated (39). In addition, counsellors, school administrators, teachers and police officers participated in focus group discussions. In this paper, the focus of discussion will be draw more heavily on students' responses.

The population comprised 1281 females and 703 males. A total of 90 students did not indicate their gender. The age range was from 4 years to 30 years with the majority of students falling between the ages of 16-20 (59 percent). In terms of the location of student populations, 1183 indicated they were from urban schools, while 695 were from rural schools. A total of 196 did not indicate their location. The students came from different types of schools, namely: single sex day schools - 289 students; single sex boarding schools - 305; mixed day schools - 1097; mixed boarding school - 282; and university -24 .

See appendix for demographic information of study participants and the responses from research questionnaires.

\section{Data Analysis}

\section{Findings}

From the students responses 4.4 percent reported having been forced into sex by someone in the school, yet 10.2 percent reported that there were incidences of sexual 
violence in schools. Also, 19 percent of the participants said they knew someone who had been sexually abused and this was mainly by fellow students (11.8 percent), and (2.9 percent by a teacher). 10.8 percent indicated that they knew of rape cases in school and 522 students expressed fear that some students had been sexually abused in school - that is 25.2 percent of the responses.

It was obvious that majority of the students were satisfied with the measures that their schools were taking to protect them from sexual abuse. However, a majority (60.1 percent) did not know of any laws dealing with sexual abuse. An overwhelming majority (83.2 percent) also said that they were taught about HIV/AIDS, an indication that schools were trying to address the issue of HIV/AIDS that they noted was of concern to them.

In all the schools visited, very few schools had experienced cases of sexual violence on the school compound. Most of the students and teachers indicated that it was not happening. Again, this was very contradictory based on the evidence provided earlier. However, a number of schools had experienced unrest due to poor diet, bad teachers, or school conditions in general.

\section{Emerging Themes}

The emerging themes that were identified, I refer to as knowledge claims.

\section{Culture of Denial and Silence}

Almost at the beginning of all focus group discussions, there was denial of any sexual violence in schools or any cases of rape. Yet, when explored further, some students or teachers would gather courage and report that there were a few rape cases or sexual violence incidences in some schools. We sensed a culture of silence that confirmed the saying: "Do not wash your dirty linen in public." It was interesting to note that those who wanted to talk would start talking in non-coherent ways saying: "Well, rape is an inside game done in the dark, how would one know it is done? Anyway we have met people who have been raped... madam even if I have been raped I don't think I can talk about it, it is shameful."

Both students and their teachers feared disclosing this information as it could easily lead to further brutality, even from the police. What was also interesting to note was that violence was also associated with fear of examinations, political influence, teachers who wanted to discredit their principals if they were competing for leadership positions, and peer pressure, especially where students had comparative needs and social class. In some areas, students feared to report the incidents due to cultural norms. For example, among the Giriama and Miji-Kenda in the Coast Province of Kenya, rape is not condoned and there is heavy penalty imposed on the offender. In these schools, the students refused to have any discussion regarding issues of sexual violence in their school. In some other cases, the students spoke and gave examples of some of the incidences that they were aware of. For example, Rukia, a primary school remarked:

There is a girl in grade two in this school... uuuum she is maybe 8 years old. This girl was raped by her father. When she reported the case to her mother, she was told to keep quiet otherwise the dad will stop providing for them. When this girl came to school, the class teacher noticed that she was walking 
in a fun manner, and she was bleeding and constantly peeing on her self. When the teacher asked her what the problem was, she said that she was hurt by her Dad and her mother had told her not to tell the teachers. When the mother was contacted, she said the child is crazy; it was not her husband but a relative who has since run away. When the school reported the case to the local police, nothing was done... The school took the girl to hospital for treatment... we do not know whether she has HIV.... She is always alone and does not talk much... Rumor has it that the girl is still been abused by her Dad and the teachers have said there is nothing they can do about it (Focus Group 3, April 2006).

In this particular incidence there is evidence of both psychological and physical abuse. The mother of the child fears her husband and as a result cannot protect her own child. The school authority feels helpless because although there is a new law dealing with sexual violence in Kenya, it is ineffective. Both the child and mother have become silent victims of a crime that can be stopped.

It is, therefore, quite clear that there is a big gap between the older members of the community and the younger members. Hence, some of the young people have been raped by people older than them or even by close family friends. Some of the young ones feel the older members have power and right over them, such as being obedient or paying them back for their kindness, for instance, when they say things like, "But uncle has been so good to me, he has helped me pay my school fees." In some focus groups, there was fear as to how this information was going to be used and if it may have implications later on.

People need information to be able to make informed decisions about whether to keep denying something that is destroying them from within, such as rape, or to seek help. They need to learn the consequences of denial, how it can lead to a maladjusted personality and create tension in a school or community. Perhaps providing written brochures in the schools to disseminate information could help with these issues of denial. This calls for urgent awareness raising and interactive forums in various schools in Kenya for youth, and especially girls, to foster an ongoing engagement and discussion about the problem and to provide ways to empower them. There is an even bigger need to have workshops for teachers in all schools to educate them in terms of their social and cultural responsibility towards their students. It is quite clear that the social cultural fabric that held many African communities together has been eroded. Children are no longer the responsibility of their community, which makes the famous African dictum, it takes a village to educate a child, a thing of the past.

\section{Poverty in society}

From the discussion groups, it was very clear that poverty was one of the issues that led young girls to agree to engage in sexual acts. Some young people accept as little as $\$ .20$ (twenty cents) to buy a mandazi (donut) in exchange for sexual favors. When they discover that this is one way they can get what they need, it becomes business as usual for them, which exposes them to risks of contracting HIV/AIDS and sexually transmitted diseases. This problem was worse in the slums and in the rural areas where the children were easily exploited as they were more ignorant than their urban counterparts. This link 
between poverty, sexual violence and HIV/AIDS is confirmed by Njeri, Najala and Jerusha who noted:

Three girls aged 11, 12, 14 years old met one of their neighbors (60 year old man) who offered to give them twenty shillings each to buy donuts in return for sexual favors. Once the act started with the first girl, the other two got scared and ran away when they realized what was happening to their friend. They screamed and alerted people who beat up the old man and then called the police. This man was however, released a day later. Some people say he paid the police men to release him. The girl that was raped got pregnant... 12 years and currently; rumor has it that she is sick with HIV/AIDS ... the mother was later beaten by her husband and blamed for their daughters behavior" (Group focus 5, April 2006).

This narrative shows that neighbors take advantage of poor girls. The quote is one of the 409 cases of rape in the schools visited. According to a report by the Gender Violence Recovery Center of The Nairobi Women's Hospital, 60 percent of sexual abuse survivors who were attended to knew their perpetrators. However, there was a lot of denial about whether anybody had been raped or not in our research. Yet, in other parts of the questionnaire the majority would say there is rape in the schools. For example, from the statistical data, 522 students were worried about being sexually abused in their school, in addition, 619 students knew of rape victims who had been tested for HIV/AIDS and they also knew that 440 had been given medicine to prevent them from contracting HIV/AIDS. From the findings, the questions that need to be addressed are: How should we deal with the issue of poverty? How can we increase peoples' earning power? What type of psychosocial support do we need to put in place? There is a need to introduce feeding programs in both Primary and Secondary schools in Kenya. This can be a joint effort between the government, parents and community members. Additionally, Kenyans should support Njoki Ndungu's Bill on Sexual Violence in Kenya - a Bill that was resisted by many members of Parliament. The Bill generated lots of interest among lay people and became a conversational topic among many Kenyans in 2006. Moreover, there should be an immediate directive from the Ministry of Education that schools should take up issues concerning their students even if they occurred outside school boundaries or outside school time.

\section{Characteristics of Sexual Defilement}

During the discussion with police officers and teachers, there was an acknowledgement that there were recorded cases of sexual abuse that had been formally reported to the police. For example, in a police station in Nyanza, between January and July 2006, 14 cases of child defilement had been reported and entered into the Daily Criminal observation book. All these cases were in court and by the time of the interview in July, 2006, 3 cases had been prosecuted with one of the offenders having been sentenced to 7 years in prison after having defiled an 11-year-old girl. The children that had been defiled were between the ages of 4 and 14 years. Most of them were orphans from the slums. There was a case of a male primary school head teacher who had defiled 7 primary school pupils. The head teacher had since gone into hiding and a warrant of arrest had been issued for him. In other Provinces, teachers reported similar incidences 
and expressed their frustration due to the fact that nothing was being done to stop this menace. Two schools in the Eastern province stated that they had reported the rape cases to the police in their area. However, as seen in the response below from one of the teachers in a focus group discussion, there was no evidence that anything had been done about them:

Sometimes it is difficult to make sense of these sexual assaults to schoolgirls and boys. In this school, we have tried to address these issues during parents' day meetings. We have even reported these matters to police; somehow, the cases disappear in thin air. It is very frustrating.... We have also asked the students to lets us know if anything happens to them. In addition, we have sex education class and in these classes there has been lots of stress on issues of HIV/AIDS... we do not know what do because in some schools, teachers will teach about these issues, then defile the student... (Focus group with Teachers, May 6, 2006).

This narrative shows the frivolous treatment that rape and other violence cases receive in Kenya and Uganda. There is urgent need for stiffer penalties for offenders; establishing a Children's Court that would strictly handle cases related to children. This would help hasten the prosecution process; financing the existing children's protection unit that would facilitate in purchasing of equipment needed to take care of defiled children; and the need to sensitize the public on the importance of community policing. This would help in netting the parents who colluded with the perpetrators in covering up the crime.

\section{Innocence of Girl-Child Claimed by Sexual Violence.}

Common acts of violence in Kenyan schools include physical beating by teachers, sexual and psychological abuse, harassment and assault of new students, rape, malnourishment of children, student unrest/strikes leading to damage of property and loss of lives among other acts (UNFPA, n.d.). Sixty-one students indicated that the teachers participated in the evil act of raping their own students. Some students stated this blatantly during the focus group discussion. In addition, the girls indicated that their fellow boy students took advantage of them - statistical data indicated there were 245 cases of rape was by fellow students. Others who took advantage of girls were school cleaners, school watchmen, parents, boyfriends or strangers.

The available media reports reveal that since 1991, not a year has gone by in Kenya without at least one incident of school violence. These incidents show that, to a greater extent, it is mainly girls who have been victims of sexual violence. When our research team visited these schools, the school authority was not willing to talk about the incidents. Most of them felt the incidents were not just mere incidences of violence but evidence of societal problems. A teacher in one of the schools visited made the comment below:

Girls are always the target in these cases. Although there has been cases of boys been raped, it is not as frequent as it is with girls. Last week, three girls were raped by a gang of 10 men. Although some of the men were arrested, they have since been released. What about our girls? Will they ever be released from this trauma? As a head of school, I feel helpless. I need support from the community 
to act on some of incidences that happen in my school. Most of the times, when a girl has been raped and later on we find out she is pregnant, I encourage her to go back to school after delivery of her child. I usually arrange for her to go to another school... so as to avoid social stigma.... Last year, one of our students died due to AIDS. The mother was too sick (HIV/AIDS) to organize her funeral, so the school arranged everything.... This was one of those cases, where we knew this girl was being assaulted by her mother's boyfriend, but we could do nothing. The boyfriend has since died. I guess it is a matter of time, before the mother dies... It is always the girls schools that are always the target.... it is always the girls who are the main targets (Focus Group 8 with Teachers, May, 2006).

The above response confirms the gendered violence in Kenyan and Uganda schools as reported in numerous media reports for the last 15 years. Violence against girls is a topic that, for a long time, has often been discussed outside of the school environment.

\section{Cultural and systemic barriers for the Girl-Child, the root cause of violence in Kenyan schools}

I think most of these rape cases take place because girls are expected not to question older people. It is therefore important for us teachers to identify and understand the social-structural factors that support sexual violence in our society. We cannot eliminate sexual violence in schools when our communities are doing nothing to protect girl-child (Focus Group 6 with Teachers, May 2006).

Teachers and Police Officers focus group provided information on some of the causes of sexual violence in schools. For instance, the police officers noted that among the Luos, during funeral rites, many adolescent girls were forced to engage in sex during funeral dances that form part of the burial rituals. The dances took place at night as a way of mourning the dead. Many girls who attended these dances usually did so without necessarily having sexual intentions. Many of those who were raped did not report their assaulters as it became difficult for them to convince people of their innocence.

Drug use was also confirmed by students, teachers, and police officers as being one of the causes for sexual violence. This is because many youth involved in the use of drugs has led to an increase in vices like the defilement of young children. Both teachers and police officers noted that most of the penalties against the offenders were not stiff enough to act as a deterrent. As well as the fact that it was easy to bail out the offender as the amounts requested were usually not very substantial. It was noted that as soon as the accused was released on bond they would normally disappear and some would even end up violating other children in the process. Some families even colluded with the offenders who paid off the parents to withdraw the cases or even encourage them not to report them at all. An important step to addressing this question of fear is to sensitise people on their rights, to have a police force who protect people of integrity in society especially those that give vital information leading to law and order in society. This could be done through workshops involving the police and social workers either through the media or at district levels by going to the schools to train the students and affirm to them what their 
rights are; especially if they find themselves raped. Law in Africa is compromised a lot even by the people who should protect it.

\section{Making sense of the Wave of Sexual Violence in Schools}

Is it stress, peer pressure, drug abuse, media influence? The study provided an entry point for understanding the social, cultural, and political factors that may contribute to increased risks of sexual violence against schoolgirls and the spread of HIV/AIDS among youths. Devising strategies and tools for responding to these challenges is crucial, considering the fact that 23 million adults in Africa aged between 15 and 49 are living with HIV/AIDS and that young women and girls aged 15-24 are now more than 3 times more likely to be infected than young men (UNICEF/UNAIDS 2003). From this study, I infer that a number of factors contribute to the limited attention paid to the problem of sexual violence in Kenyan and Ugandan schools. These include: lack of clear legislative framework to address the vice-until 2006, there was no specific parliamentary act that dealt with gendered violence in schools or outside; urbanization and the disintegration of African traditional values and family structure; media and peer influence; patriarchy in the African society; and a school system which emphasizes Eurocentric education at the expense of indigenous African cultures

\section{Recommendation and Implication for Education Policy Development}

1. There is a need for a curriculum that builds up the self-esteem of the students and does not make the teacher a know-it-all. Teachers should be encouraged to use discovery and higher order thinking in students so that they can see what they are capable of. Hence, they would not be targets of abuse that is precipitated by low self -esteem.

2. Sensitization of men together with tougher punishment - this was cited as the best long-term solution to the problem.

3. There is a need to reorganize the legal system so that it is more sensitive to children especially those that have been defiled. Stiffer penalties should be put in place.

4. There is a need to educate both boys and girls as to their rights especially with regard to sexual abuse and how to seek recourse in case they are violated. Hence, there is a need to integrate these messages in the school system.

5. All schools should adopt the Njoki Ndungu report as soon as possible.

6. All schools should reevaluate the HIV/AIDS curriculum with emphasis on behavior change.

7. Investigate further whether there is a relationship between poverty and sexual assault.

8. Sensitize teachers in all schools regarding sexual violence and ways of identifying sexually violated children.

9. There is need for more research in this area.

10. Offer courses on conflict \& anger management in a non-violent manner.

11. Sensitize teachers to detect students at risk by offering them courses in this area.

12. Improve channels of communication between all parties.

13. Create policies that deal with sexual harassment and violence. 
14. Provide confidence-building workshops for girls.

15. Increase parental involvement.

16. Curriculum should be gender sensitive.

\section{Discussion}

The education sector has also fallen victim to the expression of gender violence as is evident from media reports. However, there has been limited research on gender violence in schools due to the subject being overshadowed by the generic definition of school violence which classifies all negative incidences taking place within the school as school violence (Owinyo, 2006). As a consequence, only when victims of gender violence die does it attract media attention, public condemnation and a reactive response by the government, which later subsides until the next tragedy. Dunne et al. (2003) attempt to explain that the school offers a central space for the expression of gender violence due to the fact that, as a social arena, it is marked by asymmetrical power relations that are enacted not only through gender but also through age and authority. As a result of these structural asymmetrical power relations of schooling, the excessive use of disciplinary sanctions may lead to abuse by those in positions of authority, for instance, such as the teachers, administrators and prefects, and also by those who are able to exercise control through other means such as physical strength or economic advantage, for instance, through male or female colleagues.

In this regard, the challenge for the education sector in developing countries is greater in coping with gender violence and the risk of HIV/AIDS infection to the girl-child, since their disadvantaged position in coping with it and their greater suffering from its effects stem from skewed power relations and concepts of masculinity that undermine their right and ability to make their own decisions in the family and in society in general (Dunne et al., 2003; Owinyo \& Wildemeersch, 2005). Mirsky (2003) observes that when sexual harassment or violence is ignored in educational settings, or where young people are not taught how to recognize and avoid behaviour in their relationships, they are at a greater risk of sexual and reproductive and HIV infections. In essence, the role of education as a key defense against the spread of HIV/AIDS and gender violence cannot be ignored since it is able to reach out into the communities, however, as this discussion has highlighted, a concerted action by all stakeholders is vital for it to be effective. Hyde et al., (2001) in their studies in Uganda, observe that the resolve by the Ministry of Education to address the issue, leading to the expulsion and imprisonment of some teachers and male students who have had sex with under-age girls, has had a positive impact in reducing sexual misconduct and violence in schools. In essence, this calls for further research into the prevalence of these incidences within the education sector, the risks involved in transmitting the scourge and, through these relevant insights, conclusions may be drawn that will facilitate action by all stakeholders to make schools, not only safe havens for the girl-child, but to also initiate a process to rethink the values being transmitted in education and, particularly, how gender differentiation is being perpetrated.

Stemming from the above discussion, a pertinent contradiction emerges on the role of the school, which, as Kyungu (1999) posits, is expected to be the space in which growth and development of an individual occurs. Schools are entrusted agents of change, of liberation and conservation of what is considered to be the norms of the society. 
However, it is evident that these institutions of learning have also become unsafe havens for the women and the girl-child. Since schools are a microcosm of society, it may be likely that the increased poverty, unemployment, social and cultural disintegration, political upheavals and the scourge of HIV/AIDS that has beset sub-Saharan Africa, contributes inadvertently to the increased incidences of school and gender violence (Owinyo, 2006). According to studies by UNICEF (2002) and WHO (2002) it is evident that the incidences of gender violence are likely to be highest in contexts with limited development of civic institutions, high levels of civil disorder, civil or political conflict, where drugs and arms trafficking is commonplace, or where heavily asymmetrical gender relations are culturally prescribed and gender based violence is considered 'normal' (Dunne et al., 2003).

\section{Conclusions}

Sexual assault exists in all levels of schooling in Kenya and this violence has been inflicted to children as young as 4 years old. Given the sensitive nature of the crime, many cases of sexual assault have gone unreported especially if they involve family members and many secondary school girls do not report rape for fear of being castigated as having consented. In addition, most children were not aware of their rights with regard to recourse in the case of sexual assault. These children relied on their parents or guardians to take action on their behalf but unfortunately most times, nothing was done. There is clear evidence in that, due to lack of knowledge, some parents would wash their daughters before taking them to hospital or police stations - this act interfered with evidence necessary to prosecute the sex offender. Despite information being passed on about the dangers of HIV and AIDS to the students, there was evidence that many students were sexually active. This conclusion was arrived at due to evidence of an increase in the number of STD cases in the schools being reported.

Note

All the names of schools and participants used in the paper are pseudonyms.

\section{References}

Abagi, O. (2001). Situational Analysis of Education in Kenya. Background Document prepared for Action Aid Kenya.

Aduda, D. (2001). Radical Changes in Teacher Training Sought. Daily Nation. September 3.

Akiba, M., G.K. LeTendre, D.P. Baker and B. Goesling. (2002). School victimization: national and school system effects on school violence in 37 nations, American Educational Research Journal, 39, 4, 829-853.

Appiah, C.D. and K. Cusack. (eds) (1999). Violence against Women and Children in Ghana: Report of a National Study on Violence. Accra, Ghana: Gender Studies and Human Rights Documentation Centre.

Atemi, J.O. (2000). "Why violence and rape thrive in schools." The Daily Nation Newspaper, May 1, 2000. 
Coalition of Violence Against Women (COVAW), (2005). Gender and sexual Violence in Institutions of Learning: Calling for a Change in Attitude. COVAW.

Dunne M., S. Humphreys and F. Leach. (2003). Gender and Violence in Schools. Background Paper for the UNESCO EFA Global Monitoring Report 2003/4.

Dunne M., S. Humphreys and F. Leach. (2006). Gender and Violence in Schools in the Developing World. Gender and Education, 18,1,75-98.

Dunkle, K., R. Jewkes, H. Brown, G. Gray, J. McIntryre and S. Harlow. (2004). "GenderBased Violence, Relationship Power, and Risk of HIV Infection in Women Attending Ante-natal Clinics in South Africa." The Lancet, 363(9419): 1415.

Elimu Yetu Coalition (EYC). (2003). Reform Agenda for Education Sector in Kenya: Setting Beacons for Policy and Legislative Framework. Commonwealth Education Fund.

Gordon, P and K. Crehan. (1999): Dying of Sadness: Gender, Sexual Violence and the HIV Epidemic, UNDP Issues Paper.

Hyde, K., A. Ekatan, P. Kiage and C. Barasa. (2001). The Impact of HIV/AIDS on Formal Schooling in Uganda. Brighton: Centre for International Education, University of Sussex.

Jewkes, R., J. Levin, N. Mbananga and D. Bradshaw. (2002). Rape of girls in South Africa. The Lancet, 359, 319-320.

Kelly, M. (2003). Planning for Education in the Context of HIV/AIDS. Paper Presented at National Education Conference Nairobi. November.

Kyungu, S.M. (1999). Leadership and Discipline: The Role of Prefects in Schools. Paper Presented at the National Conference on Student Leadership, Delinquency, Guidance and Pastoral Care in Schools. Kenyatta Univ. August 16.

Leach, F. and P. Machakanja. (2000). A Preliminary Investigation into the Abuse of Girls in Zimbabwean Junior Secondary Schools. DFID Education Research No. 39, London: DFID.

Leach, F., V. Fiscian, E. Kadzamira, E. Lemani and P. Machakanja. (2003). An Investigative Study into the Abuse of Girls in African Schools. London:DfID.

Mirsky, J. (2003). Beyond Victims and Villains: Addressing Sexual Violence in the Education Sector. London: PANOS

Mumero, M. and A. Onunga. (2001). Kenya: AIDS No Scare for Prostitutes. [Online]Available at: http://www.africafiles.org/article.asp?ID=343

Maman, S. and J. Campbell (2000). The Intersections of HIV and Violence: Directions for Future Research and Interventions. Social Science \& Medicine, 50, 459-487.

Njagi, D. (2005). No Respite for AIDS Orphans. [Online] Available at: http://www.africafiles.org/article.asp?ID=7551

Oppenhiem, M (1994): HIV Transmission and the Balance of Power between women and Men: a global view in Health Transition Review, Supplement of Volume.

Ohsako, T. (ed) (1997) Violence at School: Global Issues and Interventions, Paris: UNESCO/IBE.

Otieno, W. (2000). Development of Education in Kenya: Policy Challenges in the 21st Century. Paper Presented at a Seminar for Secondary School Head Teachers, organized by the Christian Churches Educational Association (CCEA) at the Oceanic Hotel, Mombasa December 5th. 
Owinyo, S. and D. Wildemeersch. (2005). Trouble with Boys? A Critical Analysis of School and Education in the Post-Colony: A Case Study Research in Kenya. Paper Presented at the Childhoods Conference. University of Oslo June 28th-3rd July.

Owinyo, S. (2006). Caught In-Between: Exploring The Complexities Of School Vandalism. Case Study Research In Kenya. (Dissertation). KuLeuven: Belgium.

Republic of Kenya, (2001). Task Force Report on Student Discipline and Unrest in Secondary Schools. Ministry of Education Science and Technology.

Terefe, D. and D. Mengistu. (1997). Violence in Ethiopian schools: a study of some schools in Addis Ababa, in T. Ohsako (ed) Violence at School: Global Issues and Interventions. Paris: UNESCO/IBE.

UNAIDS (2002). AIDS Epidemic Update. Washington D.C./Geneva: UNAIDS/WHO.

UNICEF (2002). Gender, Sexuality and HIV/AIDS in Education (Summary Report). Nairobi: UNICEF ESARO.

UNICEF (2002). HIV/AIDS Education: A Gender Perspective, Tips and Tools. New York: UNICEF.

Wood, K. and R. Jewkes. (1998). Love is a Dangerous Thing: Micro-dynamics of Violence in Sexual Relationships of Young People in Umtata, Pretoria. Medical Research Council Technical Report.

World Bank (2000). Ecuador Gender Review: Issues and Recommendations. Washington D.C.: World Bank.

World Health Organization (2002). World Report on Violence and Health. Geneva: World Health Organization.

Yildiz, N.E. (2000). Situational Analysis of Basic Education in Kenya: A Country Programming Strategy for the Canadian International Development Agency (CIDA). Nairobi: CIDA.

UNAIDS (1999a) Gender and HIV/AIDS: taking stock of research and programs

UNAIDS (1999b) Reducing Girls, Vulnerability to HIV/AIDS: The Thai Approach United Nations Populations Fund (n.d.). Ending Widespread Violence against Women. http://www.unfpa.org/gender/violence.htm [2005, February 3] 


\section{Appendices}

\section{Section A: Demographic Data ${ }^{2}$}

Name of School

Valid

\begin{tabular}{|c|c|c|c|c|}
\hline & Frequency & Percent & ercent & Percent \\
\hline Not Stated & 27 & 1.3 & 1.3 & 1.3 \\
\hline 1D Secondary & 105 & 5.1 & 5.1 & 6.4 \\
\hline 2.S High & 93 & 4.5 & 4.5 & 10.8 \\
\hline Mmbeni Secondary & 32 & 1.5 & 1.5 & 12.4 \\
\hline Vallision Girls High & 40 & 1.9 & 1.9 & 14.3 \\
\hline Taiwi Secondary & 49 & 2.4 & 2.4 & 16.7 \\
\hline Keoral High & 58 & 2.8 & 2.8 & 19.5 \\
\hline Banoa Secondary & 54 & 2.6 & 2.6 & 22.1 \\
\hline Sana Girls High & 77 & 3.7 & 3.7 & 25.8 \\
\hline Kanatiri Mixed Day & 100 & 4.8 & 4.8 & 30.6 \\
\hline Secondary & & & & \\
\hline Mkeriari Secondary & 94 & 4.5 & 4.5 & 35.1 \\
\hline Abugani high & 81 & 3.9 & 3.9 & 39.1 \\
\hline Tarura Primary & 81 & 3.9 & 3.9 & 43.0 \\
\hline Gakuti Primary & 100 & 4.8 & 4.8 & 47.8 \\
\hline SSania Academy & 93 & 4.5 & 4.5 & 52.3 \\
\hline Eira Boarding Primary & 159 & 7.7 & 7.7 & 59.9 \\
\hline Dinda Primary School & 31 & 1.5 & 1.5 & 61.4 \\
\hline Titiani University & 24 & 1.2 & 1.2 & 62.6 \\
\hline Kianina Secondary & 17 & .8 & .8 & 63.4 \\
\hline Muswali Girls High School & 36 & 1.7 & 1.7 & 65.1 \\
\hline Star Girls High School & 44 & 2.1 & 2.1 & 67.3 \\
\hline Sally Girls High School & 16 & .8 & .8 & 68.0 \\
\hline Nnoka Secondary School & 17 & .8 & .8 & 68.9 \\
\hline Mamandu Girls Secondary & 22 & 1.1 & 1.1 & 69.9 \\
\hline Okuma Girls Sec. Sch. & 38 & 1.8 & 1.8 & 71.7 \\
\hline Sinyolo Girls High School & 40 & 1.9 & 1.9 & 73.7 \\
\hline Vic Day High School & 18 & .9 & .9 & 74.5 \\
\hline $\begin{array}{r}\text { Ssagam Secondary } \\
\text { School }\end{array}$ & 62 & 3.0 & 3.0 & 77.5 \\
\hline Mengona Senior School & 61 & 2.9 & 2.9 & 80.5 \\
\hline New kamp Senior School & 102 & 4.9 & 4.9 & 85.4 \\
\hline Mbiri Secondary & 102 & 4.9 & 4.9 & 90.3 \\
\hline Dama Senior Secondary & 95 & 4.6 & 4.6 & 94.9 \\
\hline Ppala High School & 106 & 5.1 & 5.1 & 100.0 \\
\hline Total & 2074 & 100.0 & 100.0 & \\
\hline
\end{tabular}

2. District

\begin{tabular}{|c|c|c|c|c|c|}
\hline & & \multirow[t]{2}{*}{ Frequency } & \multirow[t]{2}{*}{ Percent } & Valid & Cumulative \\
\hline & & & & ercent & Percent \\
\hline \multirow{7}{*}{ Valid } & Not Stated & 39 & 1.9 & 1.9 & 1.9 \\
\hline & Kwale & 214 & 10.3 & 10.3 & 12.2 \\
\hline & Mombasa & 424 & 20.4 & 20.4 & 32.6 \\
\hline & Kilifi & 56 & 2.7 & 2.7 & 35.3 \\
\hline & Embu & 530 & 25.6 & 25.6 & 60.9 \\
\hline & Meru South & 80 & 3.9 & 3.9 & 64.8 \\
\hline & Mbeere & 83 & 4.0 & 4.0 & 68.8 \\
\hline
\end{tabular}

\footnotetext{
${ }^{2}$ Please note that all these are pseudonyms of schools visited both in Kenya and Uganda
} 


$\begin{array}{rrrrr}\text { Machakos } & 24 & 1.2 & 1.2 & 69.9 \\ \text { Kisumu } & 158 & 7.6 & 7.6 & 77.5 \\ \text { Kampala } & 466 & 22.5 & 22.5 & 100.0 \\ \text { Total } & 2074 & 100.0 & 100.0 & \end{array}$

3. Location

\begin{tabular}{|c|c|c|c|c|c|}
\hline \multirow[b]{2}{*}{ Valid } & \multicolumn{2}{|c|}{ Frequency } & Percent & $\begin{array}{r}\text { Valid } \\
\text { Percent }\end{array}$ & \multirow{2}{*}{$\begin{array}{r}\text { Cumulative } \\
\text { Percent } \\
9.5\end{array}$} \\
\hline & Not Stated & 196 & 9.5 & 9.5 & \\
\hline & Urban & 118 & 57.0 & 57.0 & 66.5 \\
\hline & Rural & 695 & 33.5 & 33.5 & 100.0 \\
\hline & Total & 2074 & 100.0 & 100.0 & \\
\hline
\end{tabular}

4. Sponsor

\begin{tabular}{|c|c|c|c|c|c|}
\hline & & Frequency & Percent & $\begin{array}{r}\text { Valid } \\
\text { Percent }\end{array}$ & $\begin{array}{r}\text { Cumulative } \\
\text { Percent }\end{array}$ \\
\hline Valid & Not Stated & 764 & 36.8 & 36.8 & 36.8 \\
\hline & Church & 641 & 30.9 & 30.9 & 67.7 \\
\hline & DEB & 157 & 7.6 & 7.6 & 75.3 \\
\hline & Government & 116 & 5.6 & 5.6 & 80.9 \\
\hline & Parent(s) & 378 & 18.2 & 18.2 & 99.1 \\
\hline & FAWE & 6 & .3 & .3 & 99.4 \\
\hline & BOG & 12 & .6 & .6 & 100.0 \\
\hline & Total & 2074 & 100.0 & 100.0 & \\
\hline
\end{tabular}

5. Sex

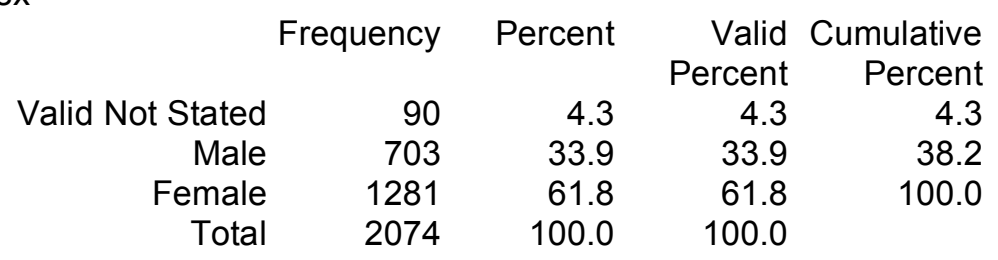

6. Age

$\begin{array}{rrrrr}\text { Frequency } & \text { Percent } & \begin{array}{r}\text { Valid } \\ \text { Percent }\end{array} & \text { Percent } \\ \text { Valid Not Stated } & 170 & 8.2 & 8.2 & 8.2 \\ 0-4 & 2 & .1 & .1 & 8.3 \\ 5-10 & 2 & .1 & .1 & 8.4 \\ 11-15 & 610 & 29.4 & 29.4 & 37.8 \\ 16-20 & 1237 & 59.6 & 59.6 & 97.4 \\ 21-25 & 48 & 2.3 & 2.3 & 99.8 \\ 26-30 & 5 & .2 & .2 & 100.0 \\ \text { Total } & 2074 & 100.0 & 100.0 & \end{array}$

7. Type of School

$\begin{array}{lrrrrr} & & \text { Frequency } & \text { Percent Valid Percent } & \text { Cumulative Percent } \\ \text { Valid } & \text { Not Stated } & 77 & 3.7 & 3.7 & 3.7 \\ & \text { Single sex day School } & 289 & 13.9 & 13.9 & 17.6\end{array}$




$\begin{array}{rrrrr}\text { Single sex boarding } & 305 & 14.7 & 14.7 & 32.4 \\ \text { school } & & & & \\ \text { Mixed day school } & 1097 & 52.9 & 52.9 & 85.2 \\ \text { Mixed boarding school } & 282 & 13.6 & 13.6 & 98.8 \\ \text { University } & 24 & 1.2 & 1.2 & 100.0 \\ \text { Total } & 2074 & 100.0 & 100.0 & \end{array}$




\section{Section B: Students Responses to the Questionnaire}

1.Have you experienced any case of violence in your school?

\begin{tabular}{|c|c|c|c|c|}
\hline & juency & Percent & Valid & Cumulative \\
\hline Ialid Not Stated & 137 & 6.6 & 6.6 & 6.6 \\
\hline Yes & 236 & 11.4 & 11.4 & 18 \\
\hline No & 1701 & 82.0 & 82.0 & 100.0 \\
\hline Total & 2074 & 100.0 & 100.0 & \\
\hline
\end{tabular}

2. Has anyone in this school forced you into sex?

\begin{tabular}{|c|c|c|c|c|}
\hline & uency & Percent & $\begin{array}{r}\text { Valid } \\
\text { Percent }\end{array}$ & $\begin{array}{l}\text { Cumulative } \\
\text { Percent }\end{array}$ \\
\hline Valid Not Stated & 17 & .8 & .8 & .8 \\
\hline Yes & 91 & 4.4 & 4.4 & 5. \\
\hline No & 1966 & 94.8 & 94.8 & 100. \\
\hline Total & 2074 & 100.0 & 100.0 & \\
\hline
\end{tabular}

3. Do you know of anyone in your school that is HIV positive?

\begin{tabular}{|c|c|c|c|c|}
\hline & uency & Percent & $\begin{array}{r}\text { Valid } \\
\text { Percent }\end{array}$ & $\begin{array}{l}\text { Cumulative } \\
\text { Percent }\end{array}$ \\
\hline alid Not Stated & 38 & 1.8 & 1.8 & .0 \\
\hline Yes & 90 & 4.3 & 4.3 & 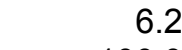 \\
\hline No & 1946 & 93.8 & 93.8 & 100. \\
\hline Total & 2074 & 100.0 & 100.0 & \\
\hline
\end{tabular}

4. Are there incidences of forced sex in your school?

\begin{tabular}{|c|c|c|c|c|}
\hline & uency & Percent & $\begin{array}{r}\text { Valid } \\
\text { Percent }\end{array}$ & $\begin{array}{l}\text { Cumulative } \\
\text { Percent }\end{array}$ \\
\hline Valid Not Stated & 67 & 3.2 & 3.2 & 3.2 \\
\hline Yes & 212 & 10 & 10.2 & 13.5 \\
\hline No & 179 & 86 & 86.5 & 100.0 \\
\hline Total & 2074 & 100.0 & 100.0 & \\
\hline
\end{tabular}

5. Do you know of anyone in your school that has been sexually abused?

\begin{tabular}{|c|c|c|c|c|}
\hline & uency & Percent & Valid & $\begin{array}{r}\text { Cumulative } \\
\text { Percent }\end{array}$ \\
\hline Valid Not Stated & 61 & 2.9 & 2.9 & 2.9 \\
\hline Yes & 409 & 19.7 & 19.7 & 22. \\
\hline No & 1604 & 77.3 & 77.3 & 100 \\
\hline Total & 2074 & 100.0 & 100.0 & \\
\hline
\end{tabular}

6. If Yes, who abused them?

Vol Stated
Teacher
A fellow student
Cleaner

$\begin{array}{rrrr}\text { Frequency } & \text { Percent Valid Percent } & \begin{array}{r}\text { Cumulative } \\ \text { Percent }\end{array} \\ 1578 & 76.1 & 76.1 & 76.1 \\ 61 & 2.9 & 2.9 & 79.0 \\ 245 & 11.8 & 11.8 & 90.8 \\ 18 & .9 & .9 & 91.7 \\ 172 & 8.3 & 8.3 & 100.0\end{array}$


school dropout, Parent,

Watchman

Total

$2074 \quad 100.0 \quad 100.0$

7. Do you know of rape cases in your school?

Frequency Percent

$\begin{array}{rrrrr}\text { Valid } \quad \text { Not Stated } & 35 & 1.7 & \text { Percent } & \text { Percent } \\ \text { Yes } & 224 & 10.8 & 10.8 & 1.7 \\ \text { No } & 1815 & 87.5 & 87.5 & 12.5 \\ \text { Total } & 2074 & 100.0 & 100.0 & \end{array}$

8. Do you know of Homosexuals or Lesbians in your school?

Frequency Percent Valid Cumulative

\begin{tabular}{|c|c|c|c|c|c|}
\hline \multirow{5}{*}{ Valid } & & & & Percent & Percen \\
\hline & Not Stated & 45 & 2.2 & 2.2 & 2.2 \\
\hline & Yes & 196 & 9.5 & 9.5 & 11.6 \\
\hline & No & 1833 & 88.4 & 88.4 & 100.0 \\
\hline & Total & 2074 & 100.0 & 100.0 & \\
\hline
\end{tabular}

9. If Yes, do you know of any students who have been forced into such activities?

\begin{tabular}{|c|c|c|c|c|c|}
\hline \multirow[b]{2}{*}{ Valic } & \multicolumn{2}{|c|}{ Frequency } & Percent & $\begin{array}{r}\text { Valid } \\
\text { Percent }\end{array}$ & $\begin{array}{r}\text { Cumulative } \\
\text { Percent }\end{array}$ \\
\hline & Not Stated & 537 & 25.9 & 25.9 & 25.9 \\
\hline & Yes & 141 & 6.8 & 6.8 & 32 \\
\hline & No & 1396 & 67.3 & 67.3 & 100.0 \\
\hline & Total & 2074 & 100.0 & 100.0 & \\
\hline
\end{tabular}

10. (a) Can one contract HIV through lesbianism?

\begin{tabular}{|c|c|c|c|c|c|}
\hline \multirow[b]{2}{*}{ Valid } & \multicolumn{2}{|c|}{ Frequency } & Percent & $\begin{array}{r}\text { Valid } \\
\text { Percent }\end{array}$ & Cumula \\
\hline & Not Stated & 230 & 11.1 & 11.1 & \\
\hline & Yes & 1063 & 51.3 & 51.3 & \\
\hline & No & 781 & 37.7 & 37.7 & $10 c$ \\
\hline & Total & 2074 & 100.0 & 100.0 & \\
\hline
\end{tabular}

11 (a) Do you know of anyone in your school who is worried of having contracted HIV?

Frequency Percent Valid Cumulative

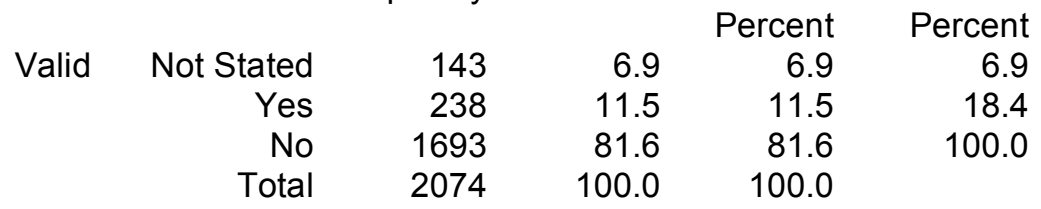

12. Are you worried because they were sexually abused in your school?

\begin{tabular}{|c|c|c|c|c|c|}
\hline \multirow{3}{*}{ Valid } & \multicolumn{2}{|c|}{ Frequency } & Percent & $\begin{array}{l}\text { Valid } \\
\text { Percent }\end{array}$ & $\begin{array}{l}\text { Cumulative } \\
\text { Percent }\end{array}$ \\
\hline & Not Stated & 32 & 16.8 & & $\begin{array}{c}\text { Percent } \\
16.8\end{array}$ \\
\hline & Yes & 5 & 25.2 & 25.2 & 41.9 \\
\hline & No & 120 & 58.1 & 58.1 & 100.0 \\
\hline
\end{tabular}


$\begin{array}{llll}\text { Total } \quad 2074 & 100.0 & 100.0\end{array}$

13. Do you know of anyone who was forced into sex during a school outing?

Frequency Percent Valid Cumulative

$\begin{array}{rrrrr}\text { Valid } \quad \text { Not Stated } & 97 & 4.7 & \text { Percent } & \text { Percent } \\ \text { Yes } & 148 & 7.1 & 7.1 & 4.7 \\ \text { No } & 1829 & 88.2 & 88.2 & 11.8 \\ \text { Total } & 2074 & 100.0 & 100.0 & \end{array}$

14. How would you rate the number of students that have been sexually abused in your school?

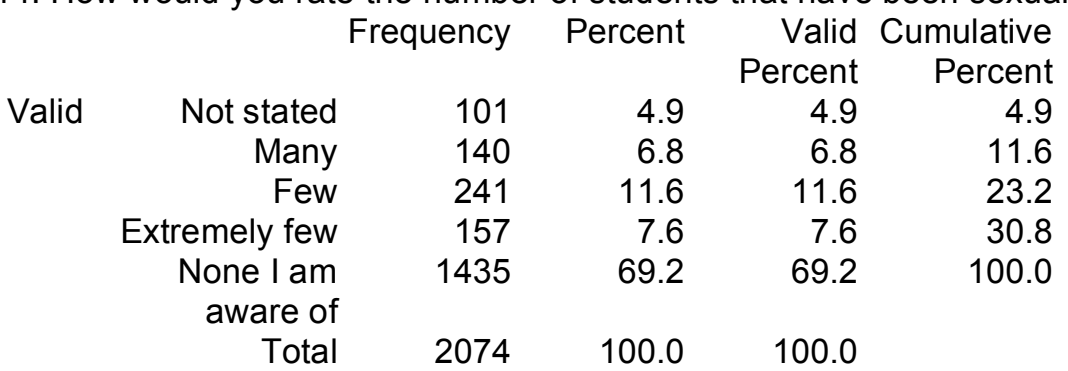

15. Do you know why a student would be sexually abused in your school?

$$
\text { Frequency Percent Valid Cumulative }
$$

$\begin{array}{rrrrr}\text { Valid Not Stated } & 649 & 31.3 & 31.3 & 31.3 \\ \text { Yes } & 805 & 38.8 & 38.8 & 70.1 \\ \text { No } & 620 & 29.9 & 29.9 & 100.0 \\ \text { Total } & 2074 & 100.0 & 100.0 & \end{array}$

16. How satisfied are you with the measures your school is taking to protect you from sexual abuse?

\begin{tabular}{|c|c|c|c|c|}
\hline & Frequency & Percent & Valid & Cumulative \\
\hline Not Stated & 159 & 7.7 & 7.7 & 7.7 \\
\hline Very satisfied & 1038 & 50.0 & 50.0 & 57.7 \\
\hline Satisfied & 539 & 26.0 & 26.0 & 83.7 \\
\hline Not Satisfied & 338 & 16.3 & 16.3 & 100.0 \\
\hline Total & 2074 & 100.0 & 100.0 & \\
\hline
\end{tabular}

17. What do you think contributed to sexual abuse?

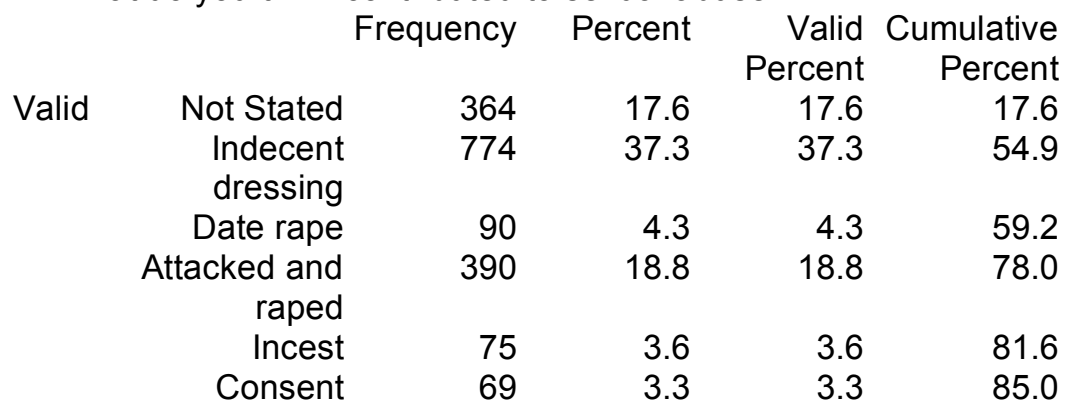




$\begin{array}{rrrrr}\begin{array}{r}\text { Commercial sex } \\ (\text { Sex for gain) }\end{array} & 312 & 15.0 & 15.0 & 100.0 \\ \begin{array}{r}\text { Total } \\ \text { Total }\end{array} & 2074 & 100.0 & 100.0 & \end{array}$

18. Are you aware of any laws dealing with sexual abuse?

\begin{tabular}{|c|c|c|c|c|c|}
\hline & & uency & Percent & Valid & Cumulative \\
\hline Valid & Not Stated & 143 & 6.9 & 6.9 & 69 \\
\hline & Yes & 685 & 33.0 & 33.0 & 39.9 \\
\hline & No & 1246 & 60.1 & 60.1 & 100.0 \\
\hline & Total & 2074 & 100.0 & 100.0 & \\
\hline
\end{tabular}

19. Were survivors tested for HIVIAIDS?

\begin{tabular}{rrrrr} 
& Frequency & Percent & \multicolumn{2}{c}{ Valid Cumulative } \\
Vercent & Percent \\
Valid Not Stated & 399 & 19.2 & 19.2 & 19.2 \\
Yes & 619 & 29.8 & 29.8 & 49.1 \\
No & 1056 & 50.9 & 50.9 & 100.0 \\
Total & 2074 & 100.0 & 100.0 &
\end{tabular}

20. If yes, were the survivals given medicine to prevent contracting HIVIAIDS?

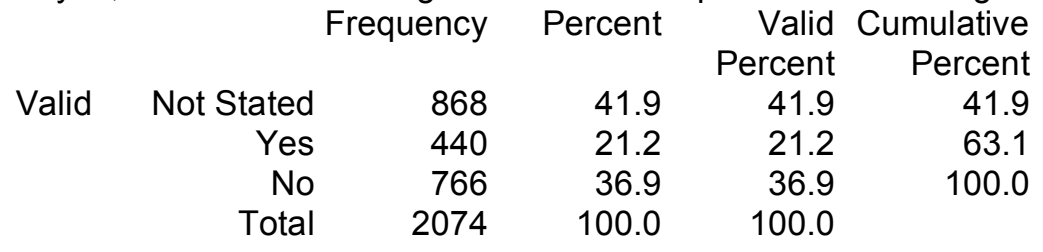

21. Are you taught about HIVIAIDS?

$\begin{array}{rrrrr} & \text { Frequency } & \text { Percent } & \text { Valid Percent } & \text { Cumulative Percent } \\ \text { Valid Not Stated } & 64 & 3.1 & 3.1 & 3.1 \\ \text { Yes } & 1726 & 83.2 & 83.2 & 86.3 \\ \text { No } & 284 & 13.7 & 13.7 & 100.0 \\ \text { Total } & 2074 & 100.0 & 100.0 & \end{array}$

